\title{
Sugriwa and Subali in Purwa Puppet: Descriptive Ethics Perspective
}

\author{
Afendy Widayat and Avi Meilawati \\ \{Afendy_widayat@uny.Ac.id, avimeilawati@uny.ac.id\} \\ Universitas Negeri Yogyakarta
}

\begin{abstract}
Wayang Purwa presents various aspects of life that are represented through the play of plays. Each play emphasizes various examples of events which in the context of ethics, can be learned moral teachings in it, by emphasizing the characterization of the main characters. Sugriwa and Subali figures are two figures of brothers who come from parts of the Ramayana story. These two brothers are very different in their disposition. Sugriwa's morality tends to be rude, and irresponsible, while Subali, his brother, is described as more subtle and wiser. This paper highlights the characterization of the two figures, with a descriptive ethical perspective, which takes into account the context of the wayang purwa tradition, especially the Yogyakarta style, the presentation of $\mathrm{Ki}$ Hadi Sugito and $\mathrm{Ki}$ Timbul Hadiprayitno, using the hermeneutic-heuristic method. The results obtained are that ethics in wayang purwa which are presented through plays, are inseparable from the context of wayang purwa in general, and certain Javanese way of life. Ethics in wayang purwa also does not merely describe black and white explicitly. Wayang Purwa emphasizes the ethics that become the Javanese way of life, specifically memayu hayuning bawana or memayu hayuning jagad, namely to seek the good and safety of the world
\end{abstract}

Keywords: ethics, puppet,Sugriwa, Subali

\section{Introduction}

The wayang purwa story which originally came from India, originates from the Ramayana and Mahabarata stories. Both of these stories developed rapidly in Java, so certain parts of the story became different from the original source. In Java, the two stories, Ramayana and Mahabarata, are even combined from the source of each story, into a long series of stories. Acts such as Rama Nitis and Wahyu Makutharama, became part of the story that ran from Ramayana sources to Mahabarata [1] Certain figures, such as the Panakawan, in the Mahabarata play section, often tell about the figures Sugriwa and Subali from the sources of the Ramayana play, dalam adegan alam-alaman [2]. They pretend to be Sugriwa, Subali, and Dewi Utara Kasih or Dewi Tara.

Sugriwa and Subali are the sons of Rsi Gotama and Dewi Indradi (Ditjen Kebudayaan Departemen P\&K, 1982: 421). Sugriwa and Subali have different characters. Subali, his brother had a hermit character so that he was virtuous, and tended to be wise. On the contrary, 
Sugriwa is his younger brother, who has a rough character, likes to talk harshly, gets angry easily, and is unwise. Wayang Purwa tells that both of them were involved in a dispute until Prabu Rama was involved in it. What's interesting is that King Rama sided with Sugriwa. This fact needs to be discussed more deeply in the context of wayang purwa and a descriptive ethical perspective. The data used in this paper are of a general nature, especially the characterizations of Sugriwa and Subali, presented by the puppeteers of Yogyakarta, especially the performance of Ki Hadi Sugito and Ki Timbul Hadiprayitno.

\subsection{Synopsis Sugriwa-Subali}

Sugriwa and Subali figures in the long story of Ramayana, is a part that starts from Kiskendakanda. Wayang Purwa tells us that Sugriwa, Subali, and Dewi Anjani were originally human. They chased after Cupu Manik Asthagina who was thrown by Resi Gotama, his father. Cupu was dropped in Lake Madirda. Sugriwa and Subali plunged into the lake to become monkeys. Anjani only washed her face, so only her hands and face were like monkeys. The three must then meditate so that one day they can become human again.

When Sugriwa and Subali were grown up, giant King Kiskenda named Mahesasura and Lembusura proposed for an angel in heaven named Dewi Utara Kasih. The gods felt overwhelmed by their supernatural powers, making the contest. The contest contained anyone who could defeat Mahesasura and Lembusura was entitled to get Tara. Sugriwa and Subali followed the contest. It is said that the one who entered the cave to kill both of them was Subali. Mahesasura and Lembusura are very powerful, if one falls, the other jumps over to make it alive again. Both of them were then pounded their heads to fall together. Sugriwa, who was waiting outside the cave, saw Maesasura and Lembusura's brain fluid being carried by the flow of water. Subali felt that his brother cheated because he closed the cave, eventually the two fought. This dispute ends with the defeat of Subali. He handed over the kingdom of Kiskenda and Dewi Tara to Sugriwa, as long as Sugriwa did not act rudely to Dewi Tara. When Marica, Dasamuka's servant slandered by reporting to Subali, that Dewi Tara was tortured by Sugriwa. Subali was angry and Sugriwa was thrown so that he was squeezed by a tree. Prabu Rama helped him, and killed Subali, so Sugriwa promised to help Prabu Rama look for Sinta. Later who found Sinta was Anoman, Sugriwa's nephew.

\subsection{Characterizations in Purwa Puppet And Descriptive Ethics}

Characterization is the creation of the image of a character in a literary work [3], in this case the puppet literature. The author, in this case the puppeteer, can use three ways to convey the imagery of his characters, namely by analytic, dramatic ways, and both at the same time. Puppet also displays characterizations through dialogue or events involving the character concerned.

Wayang purwa also represents Javanese view of life. Wayang purwa is a play which contains various elements of life, including problems of life and ways to react to them. Thus, the views of life are also presented to the audience, primarily through the lives of the characters. Wayang purwa is very fascinating to study through various perspectives, especially in terms of characters. [4] for example, wrote an article about wayang and national character development. [5], also researched reactualization of characters in wayang purwa in 21stcentury modern Indonesian fiction. However, both studies only discussed wayang and the characters in general terms.

[6] notes that characterizations in wayang do not generally deviate from the tradition of puppetry. The audience's familiarity with the puppet characters and their characters is very clear. Both the puppeteer and the puppet audience are familiar with the convention in terms of 
characterizations. If there is a deviation in the description by a puppeteer or writer about a particular puppet character, then the audience or reader will react as an act of correction.

The wayang purwa story features several characterizations which can be broadly grouped into groups, namely knights, giants, gods, priests or brahmins, female characters, servants, jinns (in Javanese: jim) or demons, animals that can talking, as well as objects that can move and talk. The Ramayana story cycle features monkeys who defend King Rama, who is generally of good character. The ape characters in the story originating from the Ramayana are told by personification, which is told almost like a human, but physically like an ape. The monkey figures in the stories from Ramayana are generally told as good figures, including Sugriwa and Subali.

The ascetics, brahmins or priests, in wayang, are often referred to as Rishis, or Begawans. This brahman figure is generally of good character, in accordance with the character of an ascetic. Subali is a Brahmin which is also often called the Resi Subali. This is different from Sugriwa, who in the wayang purwa is better known as the king. The character of kings in general can be distinguished from brahmins. This is one thing that needs to be discussed in an ethical perspective. One interesting discussion of Sugriwa and Subali's figures is from an ethical perspective.

Ethical problems are symptoms that occur in humans or involve the whole of human activity. Ethics study the goals that are in accordance with human nature as human beings in terms of the decision of reason, then the understanding of ethics is the embodiment of values or norms in the attitudes and actions of life aspired by reason [7]. While Rich [8] said that as a philosophical discipline of study, ethics is a systematic approach to understanding, analyzing, and distinguishing matters of right and wrong, good and bad, and admirable and deplorable as they relate to the wellbeing of and the relationships among sentien beings.

Ethics is a philosophy or critical and fundamental thinking about moral teachings and views. Ethics is a science, not a teaching. Ethics and moral teachings are not on the same level. Moral teachings say the way a person must live. Ethics wants to understand the reasons a person must follow certain moral teachings, or the reason someone can take a responsible attitude dealing with various moral teachings [9].

Ethics is the study of morality or human beings as far as morality is concerned, or ethics is the study of moral behavior. There are three ethical approaches, namely, normative ethics, metaetics and descriptive ethics. [10] explains it as follows.

Normative ethics is an ethics that not only depicts, but involves itself by presenting judgments about human behavior, for example, not only describing the custom of decapited head, but also rejecting the custom because it is considered contrary to human dignity. Another example, rejects the existence of prostitution as an institution because it is contrary to the dignity of women. Normative ethics leaves a neutral attitude by basing its position on the norm. Metaethics is ethics that speaks at the level of ethical language or language used in the moral sphere, or it can be said that metaethics learns specific ethics from ethical sayings of Metaethics included in analytical philosophy, which considers language analysis to be the most important task of philosophy, even one- only one. Between normative ethics and metaetics, often inseparable, because if you talk about moral language, of course, will also talk about moral behavior, when studying ethical utterances often also judge on the utterances. Conversely, when talking about moral behavior, by itself will reflect on the terms and language used. Descriptive ethics is ethics that describes moral behavior in a broad sense, for example customs, assumptions about good and bad, actions that are allowed or not. Descriptive ethics only depicts, does not provide an assessment, for example only depicts the custom of decapited head, without justifying or blaming the custom. Wayang Purwa, as a 
performance, is often not patronizing. Wayang Purwa reveals the story as it is, but that also does not mean that it always describes in detail and systematically, because the systematics is adjusted to the interests of the stage. Based on this, the staging of stories in wayang purwa is also not merely an explanation of descriptive ethics. In this opportunity, the characterization of Sugriwa and Subali will be presented in more detail, using the hermeneutic method.

\section{Research Method}

The discussion of this paper uses an analytical method called the hermeneutics and heuristics methods. [11], states that the hermeneutic method is very relevant for interpreting various symptoms, events, symbols, values contained in other language or cultural expressions, which appear in the phenomenon of human life. Phenomena related to human culture, among others, in the form of philosophical works, symbols in the form of language, or nonverbal symbols, works of art, dances, gamelan, rituals of belief, outlook on life, religious ceremonies, temples, ethics, and phenomena in other human lives. The purpose of hermeneutics is to search for and find the meaning contained in the object of research in the form of the phenomenon of human life, through understanding and interpretation.

The hermeneutic method is used to search for and find meaning regarding the characterizations of Sugriwa and Subali, especially in a descriptive ethical perspective. The heuristics method is used to discover the possibilities of new meanings associated with the discovery of meaning in the hermeneutic method, in interpreting or understanding descriptive ethics in characterizing Sugriwa and Subali. The heuristics method is used to find new scientific ways to solve problems, which have been found in the characterizations of Sugriwa and Subali's hermeneutics in a descriptive ethical perspective. Philosophy is less able to find new practical applications, because each theory always only explains experience and observation for a while, always open to new understanding. That fact is always richer and more mysterious than every theory, so every philosopher always starts from the beginning and looks for a new rational. Heuristics governs scientific renewal and at least provides some rules with reference to: (a) systematic discovery, (b) investigation of basic assumptions, (c) finding alternatives, (d) attention to inconsistencies, and (e) sensitivity to problems problems.

\section{Result And Discussion}

\subsection{The Events of Cupu Manik Asthagina}

The figures Sugriwa and Subali, are the brothers of Dewi Anjani. The three figures were originally humans, but became apes after the Cupu Manik Asthagina incident. The three of them were victims of Dewi Indradi, her mother, who was considered having an affair with Batara Surya. It is said that Cupu Manik Asthagina is the property of Dewi Indradi given by Batara Surya, because of their love affair. Dewi Indradi did not want to admit where the cupu came from, so she was condemned to become a monument. As for his children, he eventually became a monkey because of his mother's attitude (Ki Timbul Hadiprayitno, Banjaran Anoman story).

Judging from the story, his children should not be blamed, because they are not the subjects who commit evil. In fact, they also became victims. This also often happens in reality, 
including the appearance of illegitimate children because the actions of his father who is not responsible, does not legally recognize as his son. Ethics, basically do not know genetics, because all ethical consequences should only be borne by the person concerned directly. In fact, ethics always involves the surrounding community. Ethical acts of a person, can have an impact on his family, or even the community, his alma mater, his office, etc.

Sugriwa and Subali, were never told to blame their mother, or Betara Surya, as the agent who carried out the affair. Sugriwa and Subali then also tried to improve their situation by being imprisoned, so that both of them had a certain position, namely Sugriwa as the king in Kiskendha, while Subali was a Resi or magic priest with his Aji Pancasunya knowledge.

The incident that befell Sugriwa and Subali can be quoted as moral teachings, especially the beginning of the incident, namely the affair which in general can be stated as a negative action, which will bear the consequences. It turns out that the consequences must also be borne by the children of Dewi Indradi. The other side, Dewi Indradi actually has the right to love Batara Surya, because before getting Resi Gutama, he had fallen in love with Betara Surya. The mistake of Dewi Indradi, for not being frank with Resi Gutama, about his love, even when asked by Gutama about Cupu Manik Asthagina, she did not want to answer. On the Sugriwa and Subali Parties, as Indradi's children, it was good enough if she was willing to accept sincerely his fate, even though it was caused by his mother's actions.

The incident above, has not yet seemed to distinguish Sugriwa's character from Subali, but there had been a misunderstanding when the two became apes. Research in conjunction with the Cupu Manik Asthagina story, has been studied by Afendy Widayat and Suwardi [12] which is mainly discussed about the female character, Indradi, in the discussion of literary psychology. The study did not discuss the figures Sugriwa and Subali.

\subsection{The death of Maesasura and Lembusura}

The dispute between Sugriwa and Subali began when Prabu Maesasura and Lembusura from the Guwa Kiskendha kingdom proposed Dewi Tara in Kahyangan, and his proposal was rejected, by Batara Guru. Batara Guru made a contest, whoever can kill Maesasura and Lembusura is entitled to get Tara. Sugriwa and Subali followed the contest. It is said that Maesasura and Lembusura lived in caves. From inside the cave flowed a small river out through the mouth of the cave. Subali felt that he was older than Sugriwa and felt more powerful, so he entered the cave, while Sugriwa was told to guard the mouth of the cave. Sugriwa was told, if the river flow from inside the cave flowed white, that meant Subali's blood, and Sugriwa had to immediately close the mouth of the cave so that Sugriwa would not be killed. It is said that Maesasura and Lembusura agreed that if one of them died, one of them jumped over it, then the dead would come back to life. That fact was known by Subali, then the two giant heads were smashed to the point of breaking up, and both of them died. Their brains flow through the creek, and are known by Sugriwa as the white blood of Subali. He thought Subali was dead, so the mouth of the cave was immediately closed. Sugriwa immediately went to heaven to get Tara. Subali who was still alive in the cave felt betrayed by his younger brother, by closing the cave. Moreover, when he learned that Dewi Tara had been brought by his younger brother (Ki Hadi Sugito, the story of Maesasura-Lembusura Lena) Subali was angry at first, but finally chose to give in by giving up the kingdom of Goa Kiskendha and Dewi Tara to Sugriwa. Subali advised that Sugriwa should not torture Dewi Tara. Based on the story above it appears that Subali has a good character, willing to succumb to his younger brother, by giving up the kingdom of Goa Kiskendha and Dewi Tara, even though the one who killed Maesasura and Lembusura was himself. Subali also behaved well by telling Sugriwa not to torture Tara, who in this case Subali knew very well the character of 
her brother, who was rude. In terms of ethics, Subali's character can give moral teachings that a brother should love his brother sincerely, even though he must give something he gets very difficult. On the other hand, Sugriwa actually did not intend to kill his brother by covering the mouth of the cave. He was only following the orders of his brother, to close the mouth of the cave when the river water flowed with white blood. Even so, as a younger brother, he could have tried to find his brother, whether dead or not. He can also avenge the death of his brother, by fighting Maesasura and Lembusura. This is not done. In terms of ethics, Sugriwa is categorized as irresponsible. He is a younger brother who does not care about the death of his brother. He even then demanded the right to Goddess Tara who was actually the result of his brother's efforts. He went to heaven to get Tara. This part of the story shows that Sugriwa's characterization was relatively negative, in contrast to Subali's characterization which was relatively positive. Much of the story was retold, but no scientific research was found, especially the characteristics of Sugriwa and Subali.

\subsection{Subali Death Stories}

One time, Dasamuka felt that he would not be defeated by any supernatural powers, including the gods, except dealing with Subali, because Subali had his Pancasona knowledge [13]. This knowledge, it is said, who has it cannot die as long as it is still on the ground. It is said that Dasamuka wanted to pit Lamb between Subali and his younger brother, Sugriwa. Dasamuka told his devoted servant to turn himself into a deer, or something else, named Kala Marica. When Marica was told to become the nurse's sister, Tara, to face Subali. The sacrificial victim confronted Subali by saying that his wife, Dewi Tara, had just been tortured by Sugriwa, because of a simple mistake. Subali became angry with Sugriwa, because Sugriwa violated her ability not to torture Tara. It was then that Sugriwa was captured and thrown in the Kesambi tree, until it was sandwiched between two large trunks. Sugriwa could not escape (Ki Timbul Hadiprayitno, story Banjaran Anoman).

Anoman (Ki Timbul Hadiprayitno) or Jembawan (Ki Hadi Sugiito) were told to look for help in order to release Sugriwa's clothespin, finally getting a figure who was able to help him, namely Prabu Rama. Sugriwa, in the presence of Prabu Rama promised to help find Dewi Sinta, if she was helped to escape from the cloak of Kesambi, and was helped to kill Subali. Sugriwa has been helped out from Kesambi. He again fought with his brother, namely Subali, by using a yellow leaf necklace. When Sugriwa and Subali fought, Prabu Rama helped Sugriwa by shooting Subali. Subali initially blamed Prabu Rama for meddling in their family affairs, without giving an explanation first, but finally Subali learned that Prabu Rama was incarnated by Vishnu. Subali then gave his death to Rama. Subali was told to throw away his Pancasunya knowledge, so that his death could be perfect. When Subali was in a state of pain, and wanted to give Aji Pancasunya to Sugriwa, Dasamuka tricked him by claiming to be Sugriwa, so Dasamuka got his Aji Pancasunya from Subali (Ki Timbul Hadiprayitno, Banjaran Anoman story).

The characterization of Subali is again portrayed well, he seems to be responsible for the safety of Dewi Tara, at least he has proposed to her through the competition, though not until he becomes his wife. Subali is again hostile to his younger brother because he is considered to be in denial of his ability to protect Dewi Tara. Subali also held the principle of not disturbing other family affairs, as he pleased, thus blaming Prabu Rama. Subali is also described as an intelligent, or critical figure, after learning that King Rama is the incarnation of Vishnu.

Another version, it is told that Subali did not give Dewi Tara to Sugriwa, because Dewi Tara did not want Sugriwa. Sugriwa always tortures Subali and Subali does not retaliate, but because Sugriwa asks for revenge, finally Sugriwa is thrown to a pinch by a longan tree (Ki 
Hadi Sugito, Subali Lena's play). This version also tells Sugriwa's rudeness, and Subali's affection for Sugriwa.

Ethics that need to be discussed are the character comparison between Sugriwa and Subali, Sugriwa who is rude and irresponsible, with Subali who is kind, gentle, and responsible. An intriguing question is, Prabu Rama as incarnation of Wisnu instead chose to side with Sugriwa, who was relatively unfavorable. Lord Vishnu is a god who preserves the safety of the world, which is described as memayu hayuning bawana (converse the universe), tasked with maintaining the order of life in the world, but in that part precisely siding with a relatively bad character. Early scientific studies discussing Purwa puppet, especially about the relationship between the characters of Sugriwa and Subali, as well as the existence of Prabu Rama as Vishnu's title, have not been done by other researchers.

The problem with the incarnation of Wisnu in the wayang purwa has its legitimacy in relation to the Pancasunya aji. It is said that anyone who has the Pancasunya will always be the enemy of Lord Vishnu or his incarnation. This becomes more logical by assuming that the holder of his Panca aji, who does not die easily, tends to practice wrath, which is why he must be defeated by the god Vishnu or his incarnate. Rama as Visnu's titled knew already that it can be have dangerous effect from Pancasunya if it gave to Sugriwa by his characters. The determination of this philosophy is in accordance with the findings of the Puppet Philosophy Team (paper unpublished, 247-248) that (1) puppet ethics are not black and white, the problem of good and bad is not to be contested, but to be overcome. (2) Good and bad depend on the context and situation. Puppet does not emphasize the dichotomy of good and bad. Puppet ethics rests on moral relativism. (3) Puppet shows the basic motive of human action, namely the basic longing for harmony, which guides humans towards virtue. (4) Wayang ethics based on mysticism, namely in relation to Sang Hyang Widhi, with certain actions or steps .

\section{Conclusion}

Based on the description above, although ethics in wayang is presented all night long in the form of fragments in the form of plays, the ethics presentations are inseparable from the whole plays of the wayang purwa which are representations of Javanese outlook on life, in general.

Based on the description above, ethics in wayang is not limited to examples of figures in black and white characters, but rather is emphasized in ethics in relation to Javanese cultural backgrounds that lead to views on memayu hayuning bawana or to seek the good and safety of the world.

\section{References}

[1] Mulyono, Sri. Wayang, Asal-usul, Filsafat dan Masa Depannya, 1978

[2] Widayat, Afendy. "Metruk Menyuarakan Karakter Orang Jawa", dalam Kejawen: Jurnal Kebudayaan Jawa. Jrusan Pendidikan Bahasa Daerah FBS UNY dan Penerbit Narasi, Yogyakarta, 2006.

[3] Sudjiman. Panuti. Kamus Istilah Sastra. Gramedia Jakarta, 1986.

[4] Nurgiyantoro, Burhan. "Wayang dan Pengembangan Karakter Bangsa". Jurnal pendidikan Karakter, Tahun I, No. 1. Oktober. Yogyakarta: Universitas Negeri Yogyakarta, 2011.

[5] Nurgiyantoro, Burhan and Anwar Efendi. "Re-actualisation of Puppet Characters in Modern 
Indonesian Fiction of the $21^{\text {st }}$ Century". Journal 3L: The Southeast Asian Journal of English Language Studies- Vol 23(2): 141-153. http://doi.org/10.17576/3L-2017-2302-11, 2017.

[6] Wibisono, Singgih. "Konvensi dan Invensi dalam Sastra Pedalangan" dalam Gatra, Majalah Warta Wayang, No. 16. Jakarta: Senawangi, 1987.

[7] Solichin dan Tim Filsafat Wayang. Menyusun Filsafat Wayang. Yayasan Senawangi. Jakarta, 2011.

[8] Rich, Karen L. Introduction to ethics. Jones \& Barrtlett learning. UK. http://samples.jbpub.com, 2018.

[9] Magnis-Suseno. Franz. Etika Dasar, Masalah-masalah Pokok Filsafat Moral, Kanisius. Yogyakarta.

[10] Bertens, K. 2011. Etika. Cet. Ke-11. Gramedia Pustaka Utama. Jakarta, 2011.

[11] Kaelan. Metode Penelitian Kualitatif Bidang Filsafat, Paradigma bagi Pengembangan Penelitian Interdisipliner Bidang Filsafat, Budaya, Sosial, Semiotika, Sastra, Hukum dan Seni. Paradigma. Yogyakarta, 2005

[12] Widayat, Afendy dan Suwardi. "Wanita dan Perselingkuhan dalam Wayang Kulit Jawa: Kajian Psikologi Wanita" dalam eprints.uny.ac.id/1329/1/afendy_widayat.pdf, 2008.

[13] S.T. Widodo and K. Saddhono. "Petangan Tradition In Javanese Personal Naming Practice: An Ethnoliguistic Study." GEMA Online ${ }^{\circledR}$ J. of Lang. Stu. vol. 12 no. 4 pp 1165-1177, 2012 